\title{
The relationship between geographic space and the incidence of scorpion accidents in the context of social vulnerability
}

\author{
Relação entre o espaço geográfico e a incidência de acidentes escorpiônico no contexto \\ da vulnerabilidade social
}
Relación entre el espacio geográfico y la incidencia de accidentes escorpiónicos en el contexto de la vulnerabilidad social.

Thassiany Sarmento Oliveira de Almeida ${ }^{1}$, Maria Carolina Accioly Brelaz de Castroㄹ, Sayonara Maria Lia Fook², Edwirde Luiz Silva Camêlo², Lidiane Cristina Félix Gomes³, Tânia Maria Ribeiro Monteiro de Figueiredo², Valéria Rêgo Alves Pereira ${ }^{4}$.

\begin{abstract}
Objective: The relationship between the geographical space and the incidence of scorpion accidents in the context of vulnerability was questioned in the present study through the application of geoprocessing techniques. Methods: In order to recognize vulnerable groups, an ecological study was developed using spatial data analysis techniques of area. Results: A total of 631 cases of scorpion accidents occurred in Campina Grande/Paraíba/Brazil, with an incidence of 154.7 accidents/100,000 inhabitants and an average distance of $0.897 \mathrm{hm}$ between the cases; thus, verifying the possible relationship between accidents and the vulnerability index. Conclusion: Social vulnerability was evidenced by the magnitude in scorpion accidents, considering a higher probability (of attacks) in the most vulnerable areas; therefore, it was possible to verify that the occurrence of scorpion accidents is strongly connected to social factors, and that neighborhoods that have a population with low purchasing power, low schooling and no infrastructure were the most affected.
\end{abstract}

Keywords: Scorpion, Spatial analysis, Social vulnerability.

\section{RESUMO}

Objetivo: A relação entre o espaço geográfico e a incidência de acidentes de escorpião no contexto de vulnerabilidade foi questionada no presente estudo através da aplicação de técnicas de geoprocessamento. Métodos: Para reconhecer quais os grupos vulneráveis, foi então desenvolvido um estudo ecológico utilizando técnicas de análise de dados espaciais da área. Resultados: Ocorreram 631 casos de acidentes de escorpião em Campina Grande/Paraíba/Brasil, com incidência de 154,7 acidentes / 100.000 habitantes e distância média de 0,897 hm entre os casos; verificando, assim, a possível relação entre acidentes e o índice de vulnerabilidade. Conclusão: A vulnerabilidade social foi evidenciada pela magnitude dos acidentes com escorpiões, considerando uma maior probabilidade (de ataques) em áreas mais vulneráveis; portanto, foi possível verificar que a ocorrência de acidentes de escorpião está fortemente ligada a fatores sociais e que os bairros com população com baixo poder aquisitivo, baixa escolaridade e sem infraestrutura foram os mais afetados.

Palavras-chave: Escorpião, Analise espacial, Vulnerabilidade social.

\footnotetext{
1 Universidade Federal de Pernambuco (UFPE), Recife - PE. *E-mail: thassysarmento@hotmail.com

2 Universidade Estadual da Paraíba (UEPB), Campina Grande - PB.

3 Instituto Federal da Paraíba (IFPB), Campina Grande - PB.

${ }^{4}$ Departamento de Imunologia (CNPqAM/FIOCRUZ/PE), Recife - PE.
} 


\section{RESUMEN}

Objetivo: La relación entre el espacio geográfico y la incidencia de accidentes de escorpión en el contexto de vulnerabilidad fue cuestionada en el presente estudio mediante la aplicación de técnicas de geoprocesamiento. Métodos: Para reconocer a los grupos vulnerables, se desarrolló un estudio ecológico utilizando técnicas para analizar datos espaciales en el área. Resultados: Hubo 631 casos de accidentes de escorpión en Campina Grande / Paraíba / Brasil, con una incidencia de 154.7 accidentes / 100,000 habitantes y una distancia promedio de $0.897 \mathrm{hm}$ entre casos; verificando así la posible relación entre accidentes y el índice de vulnerabilidad. Conclusión: La vulnerabilidad social se evidenció por la magnitud de los accidentes con escorpiones, considerando una mayor probabilidad (de ataques) en áreas más vulnerables; por lo tanto, fue posible verificar que la ocurrencia de accidentes de escorpión está fuertemente vinculada a factores sociales y que los vecindarios con una población con bajo poder adquisitivo, baja educación y sin infraestructura fueron los más afectados.

Palabras clave: Escorpio, Análisis espacial, Vulnerabilidad social.

\section{INTRODUCTION}

Scorpions are arthropods, members of the Arachnida class and of the order Scorpiones (ORTIZ E et al., 2015). Scorpion stings are the most common cause of envenomation by a venomous animal, being responsible for expressive morbidity and lethality data in many parts of North Africa, the Middle East, and South America (ABOUMAÂD B, et al., 2014; CARMO AO, et al., 2015; DEVARBHAVI PK, et al., 2013; GONZÁLEZ JA and VALLEJO JR, 2013; NEJATI J, et al., 2014; PUCCA MB, et al., 2015).

Among the more than 1,600 species and subspecies described, the venom of at least 25 species are of medical importance; for example, the venom of the Tityus stigmurus species (SILVA NA et al., 2016). In Brazil there exist about 160 species of scorpions, and those responsible for serious accidents belong to the Tityus genus (SANTOS MSV, et al., 2016). In this place, the genus Tityus has a great relevance due to its high incidence: it is responsible for over 50,000 of the registered (SINAN, 2020).

The high density of toxins in scorpions derived from the Buthidae family - which belongs to the Tityus genus - correlates with the fact that these scorpions are considered the most dangerous to human health. The clinical status caused by the scorpion's toxin is known as scorpionism. Its severity and progression depends directly upon the animal species, varying from low to high (CARMO AO, et al., 2015; SANTOS MSV, et al., 2016). Accidents in the Brazil the species Tityus being responsible for accidents of medical importance, and more relevance to species $T$. serrulatus, $T$. bahiensis, $T$. stigmurus, and $T$. obscurus both for frequency and morbidity mortality (SANTOS MSV, et al., 2016).

The envenomation is related to the presence of neurotoxins with pharmacological action in Voltage-gated sodium channels (Nav) (PEIGNEUR S, et al., 2015). Scorpion venom has been proven to greatly affect the nervous and muscular systems, modulate the immune system, induce cardiac disorders, cause pulmonary edema, decrease urinary flow and alter endocrine, exocrine, reproductive, tegumentary, skeletal and digestive functions (HADADDEZFULI R, et al., 2015; PUCCA, et al., 2015). In fact, death is mainly caused by acute pulmonary edema in cases of envenomation (SANTOS MSV, et al., 2016).

Scorpionism in Brazil has increased a lot in the last decade, leading the ranks of accidents caused by venomous animals in the country (SANTOS MSV, et al., 2016). According to the last three annual reports from the System for Notifiable Diseases Information System (Sinan), 217,755 cases of scorpion accidents have been registered across Brazil in 2013, 2014 and 2015 (SINAN, 2020).

The increasing notification of these accidents and the greater frequency of severe cases with the presence of cardiopulmonary complications demonstrate the role of this aggravation on health in our country. In this context, new investigations that all MF and ow the exact investigation of its magnitude and its consequences are of great value, such as the use of the emerging technology Geographic Information Systems (SIG). In combination with field surveys and data census, these enable mapping of the risk of scorpion accidents (WENTZ EA, et al., 2014). These tools show that they have the potential to be useful in decision-making to guide emergency management and urban planning (ZHAO M and LIU X, 2016). 
Spatial epidemiology allows us to identify the frequency and distribution of the various risk factors considered in scorpionism. It also allows to identify groups that share risk determinants from the perspective of vulnerability. This means conditions of vulnerability - such as physical, environmental, technical, economic, psychological, social and political - which increase the predisposition of a community to be affected by the phenomenon and/or danger (VEYRET Y, 2013). Recognizing risk groups allows for identifying interventions aimed at mitigating or eliminating the specific determinants for health risk (ALMEIDA TSO, et al., 2016).

Therefore, the relationship between geographical space and the incidence of scorpion accidents in the context of vulnerability was questioned in the present study through the application of geoprocessing techniques.

\section{METHODS}

This is an ecological study using spatial data analysis techniques. This type of research has the objective of studying health in the environmental context. In elaborating the present study, cases of scorpionism reported between January 2016 and December 2016 were identified according to the Ciatox-CG database/Ministry of Health/Anvisa.

\section{Population and Sample}

Seven hundred twenty-nine (729) scorpion accidents were reported by the Ceatox-CG In the analyzed period. The addresses contained in the medical record were searched on the Correios website and later edited for geocoding. Ninety-eight (98) cases were excluded because they referred to non-existing addresses. The total sample obtained corresponded to 631 accidents/cases.

\section{Study area}

The study was carried out in the municipality of Campina Grande/Paraíba located in the Agreste Paraibano mesoregion, to $120 \mathrm{~km}^{2}$ of João Pessoa (the capital of the state of Paraíba), on the eastern part of the Borborema plateau (Latitude -7.23072, longitude: - 35.8817, $7^{\circ} 13^{\prime} 51^{\prime \prime}$ South, 35 $52^{\prime}$ '54" West). According to data from the Brazilian Institute of Geography and Statistics (IBGE), the municipality has a territorial area of $591,658 \mathrm{~km}^{2}$, with an urban area divided into 50 neighborhoods. According to the last Census, its demographic density was 648,31 inhabitants $/ \mathrm{km}^{2}$ with an estimated 409.731 for the year 2019 (IBGE, 2020).

\section{Inclusion criteria}

Cases registered as scorpion accidents in 2016 among residents of the urban area of the municipality of Campina Grande, whose addresses corresponded in fact to actual sites/households, and were georeferenced were included in the study.

\section{Data processing and analysis}

The following applications were used for geocoding and spatial analysis: ArcGIS 10 by Esri, Google Earth, and Trackmaker. The software programs used for geocoding were Google Fusion Tables and Google Earth (manually pinpointing cases).

Next, data conversion from the Kml format (Google Earth file) to Shp was performed in the Trackmaker extended version in order to sequentially manipulate the data in the ArcGIS 10 software by Esri. ArcGIS 10 by Esri was used for constructing the thematic maps. Finally, spatial analysis was performed through the $\mathrm{R}$ statistical program version 3.1.1 for Windows.

Microsoft Office Excel 2010 was used to count the neighborhood envenomation cases and construct spreadsheets for statistical analysis in the R statistical program (version 3.1.1 for Windows). Reference values of $p<0.05$ were used as statistically significant.

The estimated population for 2016 of the urban area of the municipality according to the last census was used in the denominator for calculating the incidence rate in the municipality and by neighborhood. It is important to note that rates calculated based on small population counts, as in the case of neighborhoods, may present problems regarding an excessive random fluctuation of their values. Thus, the Freeman-Tukey transformation was used to mitigate these problems. 
The Moran Global index was also calculated. Thematic maps were applied to better evidence the distribution patterns of intoxications/envenomation. These classes were defined by "natural breaks" that took into account the variance present in the set of values for determining the data intervals. The first map, called Kernel, refers to a statistical estimation method of density curves. In this method, standard behaviors weighted by distance with respect to a central value are analyzed.

\section{Spatial Distribution of Scorpionism Cases and its Relationship with Social Vulnerability}

Family Social Vulnerability Indexes (IVSF/FSVI) from the districts of Campina Grande/PB obtained through the demographic census of 2010 were synthesized for constructing an investigation of the municipality's residents' living conditions. The vulnerability thematic map arose from an interface that made it possible to compare the findings with the scorpionism incidence in the municipality's districts by verifying whether there are care units in the most needy areas of the city, and whether socioeconomic relationships with the cases was found, as well as to present areas that are more vulnerable to the dynamics of the disease under study.

The following variables were used for construction of the IVSF/FSVI: Households with their own water, energy and garbage collection - HWEG; Households with Bathrooms/sanitary sewage - HBSS; Number of residents in permanent households - RPH; Income between 1/2 and 1 minimum salary - I1/2 to 1S; Income between 1 and 2 minimum salaries - I1 to 2S; Illiterate population over 10 years of age - ILP >10; Literate population over 10 years of age - LP $>10$ (Frame 1).

A factorial analysis was carried out to condense the information contained in the original variables. Factors and an analysis of groupings were extracted through the principal components method to gather neighborhoods with similar conditions of life, thus providing four strata: Low, Medium, High and Very High family social vulnerability (GOMES LC and SALES MCL, 2016).

Frame 1 - Social variables used to generate the Family Social Vulnerability Index according to the neighborhoods.

\begin{tabular}{|l|l|}
\hline IBGE code & Variable \\
\hline HWEG & Households with their own water, energy and garbage collection \\
\hline HBSS & Households with Bathrooms / sanitary sewage \\
\hline RPH & Number of residents in permanent households \\
\hline I1/2 to $1 S$ & Income between $1 / 2$ and 1 salary \\
\hline I1 to $2 S$ & Income between 1 and 2 salaries \\
\hline ILP & Illiterate population over 10 years of age \\
\hline LP & Literate population over 10 years of age \\
\hline
\end{tabular}

Source: Almeida TSOA, et al., 2020.

After geocoding the scorpion accidents and visualizing the cases, the Kriging technique by indication was applied, which is a geostatistical method to highlight the areas with the highest concentration of cases; thus, areas where accidents are most likely to occur (GOMES LC, SALES MCL, 2016).

\section{Ethical aspects}

The project was approved by the Ethics and Research Committee of the Fundação Oswaldo CruzFiocruz/PE, Instituto Aggeu Magalhães (CAAE: 50968315.4.1001.5190), in accordance with Resolution $\mathrm{n}^{\circ}$ 466/2012 CNS/MS.

\section{RESULTS}

Six hundred thirty-one (631) cases of scorpion accidents took place in the urban area of Campina Grande were reported and attended by Ciatox-CG in the analyzed period and included in the study, with an incidence of 154.7 accidents $/ 100,000$ inhabitants in 2016 . Of the total cases, $60.2 \%(n=380)$ occurred among females and $39.8 \%(n=251)$ among males. Table 1 shows the sociodemographic profile of the patients according to gender. We can observe that the cases were more prevalent in the age group of $30-59$ years $(39.3 \%, n=248)$. However, the most prevalent among the male cases were children $(34.66 \%, n=87)$ and adults $(33.86 \%, n=85)$. Among female cases, adults prevailed $(43.0 \%, n=163)$ (Table 1). 
Table 1 - Characterization of the profile of scorpion sting cases attended and reported in Ciatox - CG, Paraíba, Brazil, in the year of $2016(n=631)$.

\begin{tabular}{|c|c|c|c|c|c|}
\hline \multirow{3}{*}{$\begin{array}{l}\text { Socioeconomic Variables } \\
\text { Age group (years) [n=623] }\end{array}$} & \multicolumn{4}{|c|}{ Gender } & \multirow{3}{*}{$\begin{array}{l}\text { p-value } \\
{ }^{*} 0.0013 \\
\end{array}$} \\
\hline & \multicolumn{2}{|c|}{$\begin{array}{c}\text { Male } \\
(n=251)\end{array}$} & \multicolumn{2}{|c|}{$\begin{array}{l}\text { Female } \\
(n=380)\end{array}$} & \\
\hline & $\mathbf{N}$ & $\%$ & $\mathbf{N}$ & $\%$ & \\
\hline $0-15$ & 87 & 34.66 & 83 & 21.90 & \\
\hline $15-29$ & 54 & 21.51 & 67 & 17.68 & \\
\hline $30-59$ & 85 & 33.86 & 163 & 43.01 & \\
\hline 60 or more & 24 & 9.56 & 60 & 15.83 & \\
\hline Total & 250 & 100 & 373 & 100 & \\
\hline Education level [ $n=596]$ & & & & & 0.25615 \\
\hline Illiterate & 3 & 1.3 & 7 & 1.92 & \\
\hline Incomplete $1^{\text {st }}$ to $4^{\text {th }}$ grade of Primary Education & 13 & 5.63 & 19 & 5.21 & \\
\hline Complete $2^{\text {nd }}$ to $4^{\text {th }}$ grade of Primary Education & 5 & 2.16 & 6 & 1.64 & \\
\hline Incomplete $5^{\text {th }}$ to $8^{\text {th }}$ grade of Primary Education & 24 & 10.39 & 31 & 8.49 & \\
\hline Complete Primary Education & 8 & 3.46 & 8 & 2.19 & \\
\hline Incomplete Secondary Education & 17 & 7.36 & 13 & 3.56 & \\
\hline Complete Secondary Education & 20 & 8.66 & 40 & 10.96 & \\
\hline Incomplete Higher Education & 6 & 2.6 & 1 & 3.01 & \\
\hline Complete Higher Education & 10 & 4.33 & 21 & 5.75 & \\
\hline Blank/Not applicable & 125 & 54.12 & 209 & 57.26 & \\
\hline Total & 231 & 100 & 365 & 100 & \\
\hline Race/Skin Color $[\mathrm{n}=617]$ & & & & & 0.70625 \\
\hline White & 78 & 31.97 & 134 & 35.92 & \\
\hline Black & 21 & 8.61 & 21 & 5.63 & \\
\hline Yellow & 1 & 0.41 & 4 & 1.07 & \\
\hline Brown & 137 & 56.15 & 204 & 54.96 & \\
\hline Indigenous & 1 & 0.41 & 1 & 0.27 & \\
\hline No answer & 6 & 2.46 & 8 & 2.14 & \\
\hline Total & 244 & 100 & 373 & 100 & - \\
\hline
\end{tabular}

Legend: *Values for $p<0.05$ = statistically significant. Source: Almeida TSOA, et al., 2020; data extracted from iatox-CG database, 2018 and SINAN, 2018. Accident by venomous animals - notifications registered in the notification system for injuries. 
Graphic 1 - Pearson's correlation between the gender and age variables according to the cases of scorpion accidents attended and reported by Ciatox-CG, Paraíba, Brazil, in the year of 2016 .

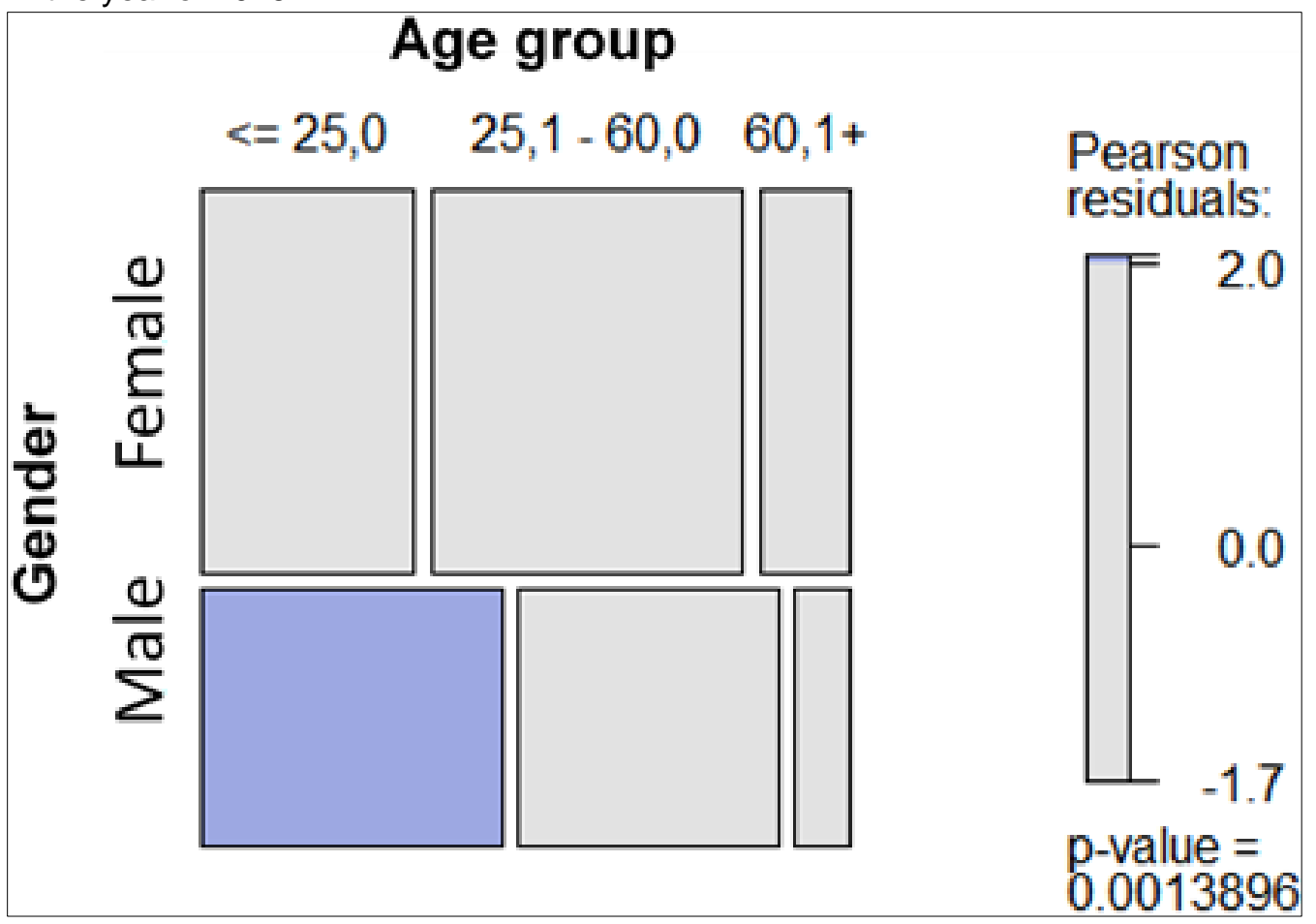

Source: Almeida TSOA, et al., 2020.

Regarding schooling, there was a predominance of men who did not conclude primary education $(\mathrm{n}=24$, $10.39 \%)$, and woman who had completed secondary education $(n=40,10.96 \%)$. We highlight that there were high numbers of abstentions/non applicable answers for both genders. Regarding Race/Skin Color, the highest numbers were observed for brown skin in both genders ( $n=137$ and $n=204$ for male and female, respectively).

Still regarding Table 1, eight cases did not inform their ages and 35 did not inform their schooling. At last, 24 did not inform their race. Therefore, the data displayed are only those contained in the patients' medical records.

According to the Pearson's chi-square test, the existence of a dependence between the variables gender and age-group was verified ( $p$-value $=0.00<0.05$ ) (Graphic 1). For the characteristic pain symptom, $94.6 \%$ $(n=597)$ of the patients reported pain. Edema and paresthesia were observed in $29.6 \%(n=187)$ and $17.4 \%$ $(n=110)$, respectively.

Other local manifestations occurred to a lesser extent such as hyperemia, ecchymosis, erythema, headache and burning, totaling $8.2 \%(n=52)$. Only $5.7 \%(n=36)$ of the patients presented parasympathetic manifestations such as diarrhea or vomiting, or sympathetic (hypertension), and therefore received Intravenous therapy; $0.9 \%(n=6)$ (of the cases) progressed to deaths.

In order to verify the possible relationship between the accidents and the vulnerability index, a thematic map showing the highest incidence in more vulnerable areas (High or Very High) was constructed. This means neighborhoods with worse living conditions (according to the IBGE data) have a higher incidence of scorpion accidents (Figure 1). 
Figure 1 - Spatial distribution of scorpion accidents attended and reported by Ciatox-CG, Paraíba, Brazil, in the year of 2016, according to vulnerability data.

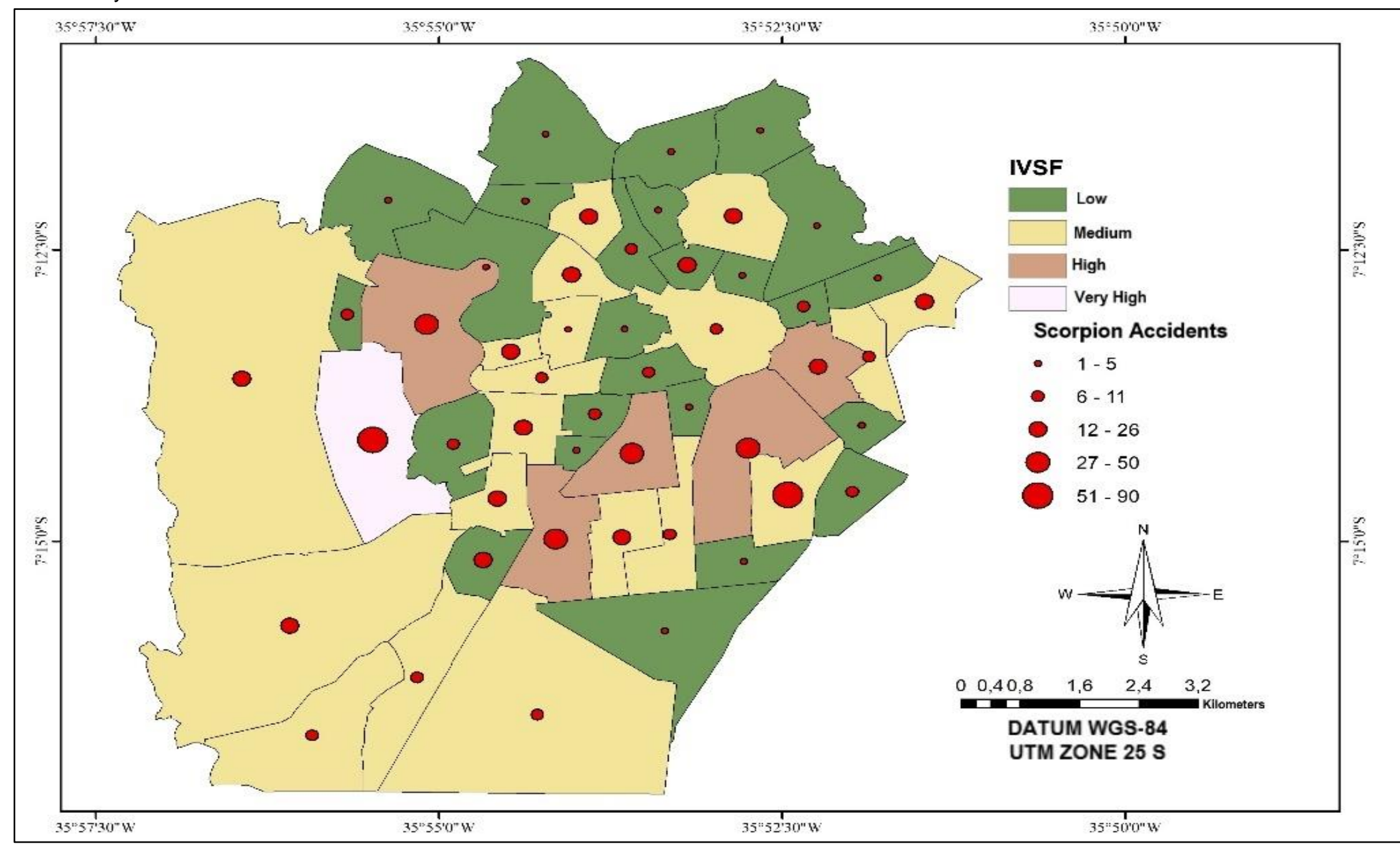

Legend: *IVSF/FSVI= Family Social Vulnerability Indexes.

Source: Almeida TSOA, et al., 2020.

REAS / EJCH | Vol.12(12) | e3950 | DOI: https://doi.org/10.25248/reas.e3950.2020 Página 7 de 12 
Among the georeferenced cases, it was possible to observe the mean distance of $0.897 \mathrm{hm}$ between the cases through calculation of the nearest neighbor (single method) (Figure 2).

Figure 2 - Distance between the scorpion accidents attended and reported by Ciatox-CG, Paraíba, Brazil, in the year of 2016 .

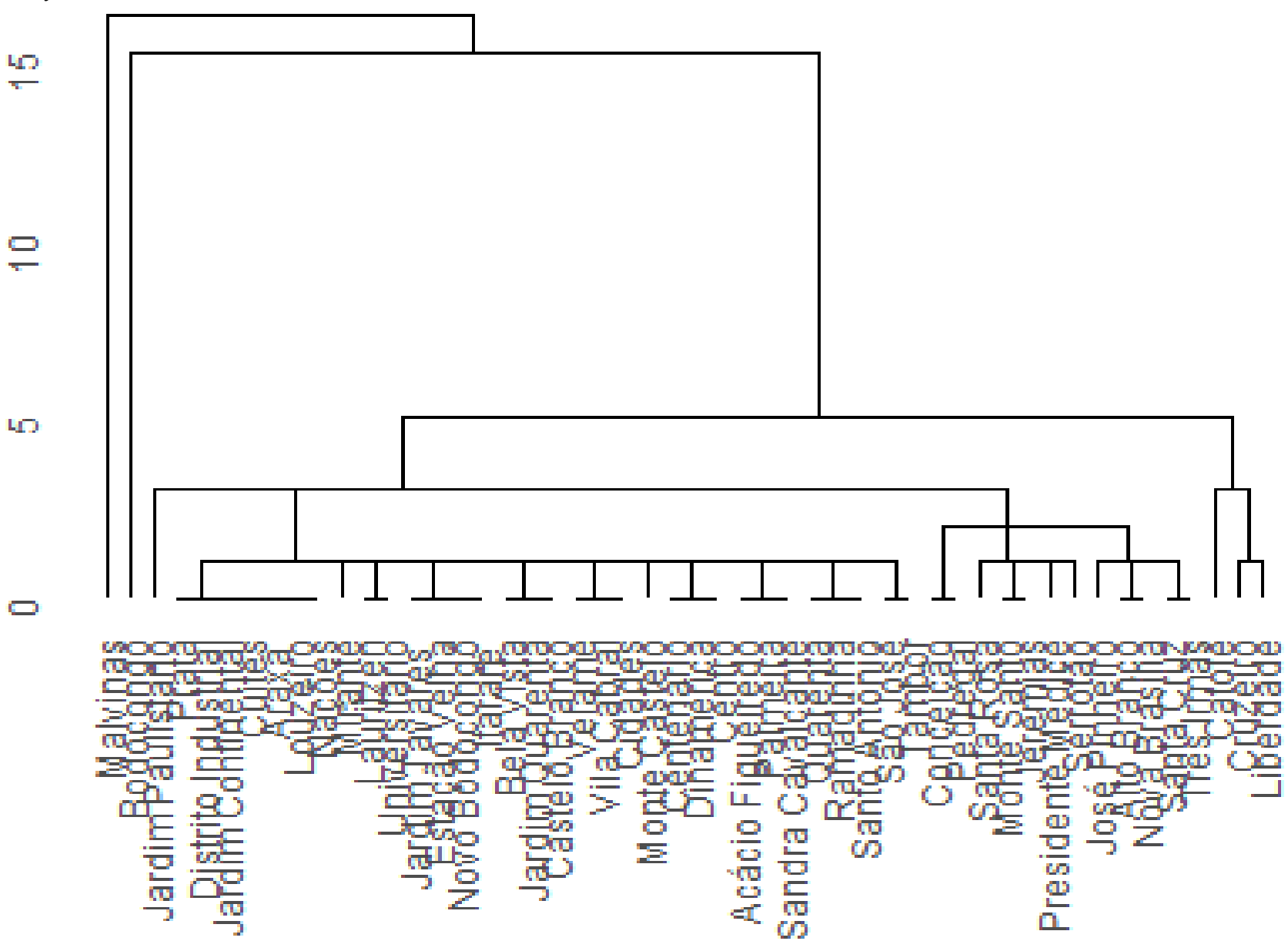

Legend: *The horizontal axis represents the neighborhoods in the following order: Malvinas, Bodocongo, Jardim Paulistano, Prata, Distrito Industrial, Jardim Continetal, Cuités, Arara, Louzeiro, Nações, Mirante, Lauritzen, Universitário, Jardim Tavares, Estação Velha, Novo Bodocongó, Itararé, Bela Vista, Jardim Quarenta, Castelo Branco, Velame, Vila Cabral, Cidades, Monte Castelo, Centenário, Dinamérica, Centro, Acácio Figueiredo, Palmeira, Sandra Cavalcante, Quarenta, Ramadinha, Santo Antônio, São José, Tambor, Conceição, Pedregal, Santa Rosa, Monte Santo, Jeremias, Presidente Medice, Serrotão, José Pinheiro, Alto Branco, Nova Brasilia, Santa Cruz, Três Irmãs, Catolé, Cruzeiro and Liberdade.

Source: Almeida TSOA, et al., 2020.

It was also possible to verify the presence of envenomation hot spots in the most central regions of the municipality through the application of the Kernel technique, with little or no record of accidents in peripheral areas of the city, mainly in the north and east zones (Figure 3). In contrast to the previous map, it is evident that these zones of greater intensity coincide with the regions of greater vulnerability.

Finally, the Moran I test for the variable education level was equal to 1.4084 , indicating the presence of a "cluster". The results were negative for the variables of gender and race, being equivalent to -0.9789 and 0.7204 respectively. These significantly low values indicate a spatial scheme of inequality in the region, a sort of "anti-cluster" pattern, or transition zones between a given space regime and another. 
Figure 3 - Estimated density of scorpion accidents by the Kernel method in the urban area of the municipality of Campina Grande/PB, according to the cases served and notified by Ciatox-CG, Paraíba, Brazil, in the year of $2016(n=631)$.

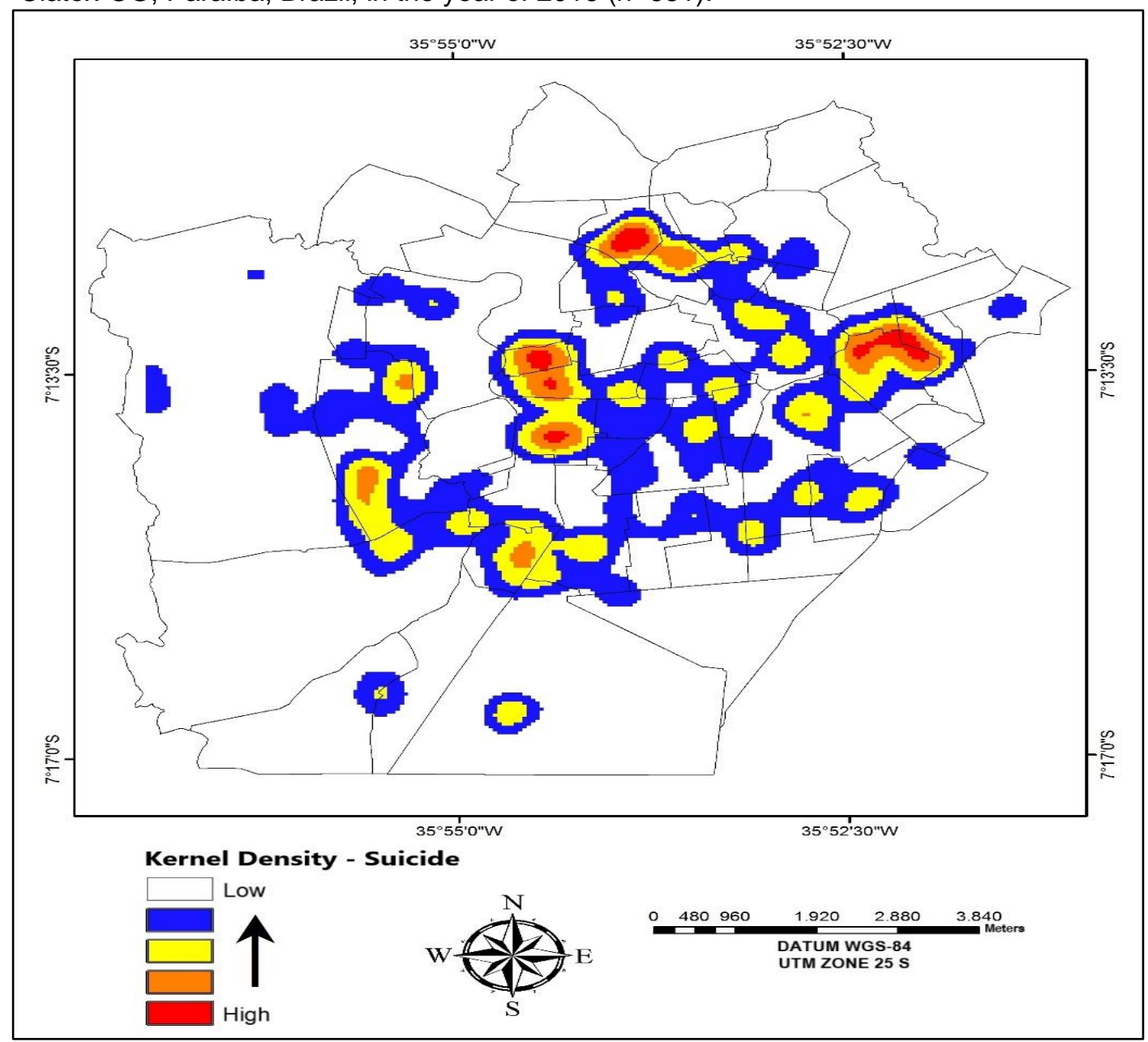

Source: Almeida TSOA, et al., 2020.

\section{DISCUSSION}

The frequency incidence and the potential severity rate of scorpion accidents were verified in analysing the obtained results (SANTOS MSV, et al., 2016). The incidence of scorpionism found of 154.7 accidents $/ 100,000$ inhabitants was higher than the various national statistics of: 8.14 cases $/ 100,000$ inhabitants throughout the country; 17.7 cases/100,000 in Amazonas and 22.4 cases/100,000 in Belo Horizonte (COSTA CLSO, et al., 2016; RECKZIEGEL GC, 2014QUEIROZ AM, et al., 2015).

It also surpassed the international data of: 140 cases/100,000 in Algeria; 41 cases/100,000 in Colombia (); 19.7 cases/100.000 in Singapura; and 129.7 cases/100.000 in Turkey (HELLAL H et al., 2012; GÓMEZ JP, et al., 2010; TAN NH and MONG R, 2013; ÜLUG M, et al., 2012). However, it was lower than a recent Iranian study that presented an incidence of 334.37/100,000 inhabitants in 2008, and 339.07/100,000 in 2009 (KHATONY AA, et al., 2015).

A higher frequency of accidents with females (60.2\%) was observed. This evidence may be explained by the different occupations and behaviors in the domicile scope, considering that scorpions of the Tityus genus have urban and peridomiciliar behavior (ALMEIDA TSOA, et al., 2015; OLIVEIRA HFA, et al., 2012; MESQUITA FNB, et al., 2015; BARROS RM, et al., 2014; VENTER O, et al., 2016).

Severe cases and deaths caused by the Tityus genus particularly occur in envenomations involving children (ALBUQUERQUE CMR, et al., 2013; BUCARETCHI F, et al., 2014). However, the cases in our sample occurred more frequently among adults, corresponding to the findings in Saudi Arabia, France and Iran. This 
fact probably arises due to this age group being exposed to greater mobility and work activities (AL ASMARI AK, et al., 2012; HELLAL H, et al., 2012; KHATONY AA, et al., 2015).

The clinical manifestations observed in scorpionism depend on the predominance of adrenergic or cholinergic effects (RODRÍGUEZ-RAVELO R, et al., 2013). In this case, the patients presented local clinical manifestations such as pain, edema and paresthesia, which corroborate with the literature; while systemic manifestations were less frequent (KHATONY AA et al., 2015; SANTOS MSV, et al., 2016). These are represented by hypertension/hypotension, showing the adrenergic effects and induced cholinergic effects by T. silvestris venom (ALBUQUERQUE CMR, et al., 2013; BUCARETCHI F, et al., 2014).

Regarding the biological effects, according to the literature the antigen of the Tityus stigmurus species (Venom-TsV) induces a transient increase in perfusion pressure and renal tubular injury (MONTEIRO WM, et al., 2016; SILVA NA, et al., 2016). Thus, mapping scorpions in different locations is essential and must be accompanied by the characterization of the main biological activities of the venom and consequent variation of the symptoms (QUEIROZ AM, et al., 2015).

The findings regarding the spatial distribution of scorpion accidents according to the Moran Index present no autocorrelation with gender, corroborating with previous findings (ALMEIDA TS, et al., 2015). Moreover, no geographic autocorrelation between race/skin colours was found. However, a "cluster" formation between the education levels indicated that this phenomenon is not randomly distributed in space. Therefore, there is a correlation in which similar levels of schooling tend to have similar incidence rates.

An association between areas of higher scorpionism incidence and areas of vulnerability was observed, contrary to previous research (BARBOSA AD, et al., 2014). This higher incidence can occur frequently in areas of older and populous favelas, characterized by the lack of basic sanitation and other substandard housing (NUNES CS, et al., 2000; KHATONY AA, et al., 2015).

The Kernel map presented here is similar to a previous study, in which areas of hot spots predominate as they approach more central regions, often being more vulnerable with cases occurring closer together (average distance of $0.89 \mathrm{hm}$ between the cases), and therefore forming a cluster. However, we can highlight the growing distribution of cases and the consequent increase of spatial density, highlighting the potential of low dispersion (ALMEIDA TS, et al., 2015; BRYSON RW, et al., 2016). Regarding the spatial pattern analysis of Buthus martensii in Yan'an, China, a distribution with greater density area or greater degree of aggregation was also observed (XU SC, et al., 2013).

This study concludes that the obtained findings regarding the Family Social Vulnerability Indexes explain the distribution of reported accidents during the study period. Other variables may be responsible for the proliferation of scorpions such as climatic variables (SANTOS MSV, et al., 2016). Applying hypothesis tests on the correlation of the accidents with the influence of wind speed, atmospheric pressure, maximum air temperature and thermal amplitude could also explain the geographic distribution. In this context, new complementary studies could be carried out.

As a limiting factor we can point out the lack of georeferencing studies on scorpions due to their condition being characterized as neglected. The lack of ecological studies including neotropical regions is not surprising, since no specialists are available, despite the high biodiversity of such environments and evidence that environmental changes are transforming the ecology of the tropics (LIRA AFA and SOUZA AM, 2014).

\section{CONCLUSION}

Scorpion envenomation can be considered a challenging medical situation. Incidence data assessed in the period of 2016 are alarming, being well above the national and international averages from Algeria, Iran, Singapore and Turkey. Social vulnerability was evidenced by the magnitude of scorpion accidents, contemplating a greater probability in more vulnerable areas. Thus, the social dimension pointed to indicators capable of revealing the profile of the population in the area and the potential risk of these accidents. It was possible to verify that the occurrence of scorpion accidents is strongly related to social factors, and 
neighborhoods that have a population with low purchasing power, low schooling and no infrastructure were the most affected. A spatial autocorrelation of incidence with schooling levels was observed which require health education actions such as the transmission of educational videos, the distribution of booklets and displays in order to promote instruction on the magnitude of the problem. After establishing hot spots and areas of high and very high vulnerability and concomitant high incidence, these priority intervention areas have been evidenced.

\section{REFERENCES}

1. ABOUMAÂD B, et al. Cardiac involvement and its complications about three cases of severe scorpion envenomation. Toxicon 2014; 78: 78-82.

2. AL ASMARI AK, et al. Clinical aspects and frequency of scorpion stings in the Riyadh Region of Saudi Arabia. Saudi Med J. 2012;33(8): :852-8

3. ALBUQUERQUE CMR, et al. Pediatric epidemiological aspects of scorpionism and report on fatal cases from Tityus stigmurus stings (Scorpiones: Buthidae) in State of Pernambuco, Brazil. Rev. Soc. Bras. Med. Trop. 2013; 46, 484489.

4. ALMEIDA TS, et al. Spatial distribution of scorpions according to the socioeconomic conditions in Campina Grande, State of Paraíba, Brazil. Rev Soc Bras Med Trop. 2016; 49:477-85

5. BARBOSA AD, et al. Distribuição espacial de acidentes escorpiônicos em Belo Horizonte, Minas Gerais, 2005 a 2009. Arq. Bras. Med. Veterinária e Zootec. 2014; 66, 721-730.

6. BARROS RM, et al. Clinical and epidemiological aspects of scorpion stings in the northeast region of Brazil. Ciência \& Saúde Coletiva, 2014; 19(4): 1282-1275.

7. BRYSON RW, et al. Genomic data reveal ancient microendemism in forest scorpions across the California Floristic Province. Mol Ecol, 2016; 25: 3731-3751.

8. BUCARETCHI F, et al. Clinical consequences of Tityus bahiensis and Tityus serrulatus scorpion stings in the region of Campinas, southeastern Brazil. Toxicon.2014; 89, $17 \mathrm{e} 25$.

9. CARMO AO, et al. Evolution of alternative methodologies of scorpion antivenoms production. Toxicon $2015 ; 97,64-$ 74.

10. COSTA CLSO, et al. A profile of scorpionism, including the species of scorpions involved, in the state of Amazonas, Brazil. Rev. Soc. Bras. Med. Trop. 2016; 49, 376-379. doi:10.1590/0037-8682-0377-2015

11. DEVARBHAVI PK, VASUDEVA MURTHY CR. Scorpion sting envenomation - an overview. J Clin Biomed Sci 2013; $3(4): 159-6$.

12. GOMES LC, SALES MCL. Comportamento Espaço-Temporal da Pneumonia e suas Relações com os Elementos Climáticos e Socioeconômicos em Campina Grande - PB, Ano de obtenção: 2016. Tese de Doutorado, UFCE.

13. GONZÁLEZ JA, VALLEJO JR. The scorpion in Spanish folk medicine: a review of traditional remedies for stings and its use as a therapeutic resource. J Ethnopharmacol 2013; 146: 62-74.

14. GÓMEZ JP, et al. icaduras por escorpión Tityus asthenes en Mutatá, Colombia: aspectos epidemiológicos, clínicos y toxinológicos. Biomédica. 2010; 30: 126-139.

15. HADADDEZFULI R, et al. Hemiscorpius lepturus venom induces expression and production of interluckin-12 in human monocytes. Toxicon. 2015; 100: 27-31

16. HELLAL H, et al. Epidemiological data on scorpion envenomation in Algeria. Bull Soc Pathol Exot. 2012;105(3):18993.

17. IBGE, 2020. Informações extraídas do Instituto Brasileiro de Geografia e Estatistica.

18. KHATONY AA, et al. Journal of Venomous Animals and Toxins including Tropical Diseases. 2015. 21:45

19. LIRA AFA, SOUZA AM. Microhabitat use by scorpion species (Arachnida: Scorpiones) in the montane Atlantic Rain Forest, Brazil. Rev. Iber. Aracnol. 2014; 24:107-108.

20. MESQUITA FNB, et al. Rev. Fac. Ciênc. Méd. Sorocaba, 2015; 17 (1):15 - 20.

21. MONTEIRO WM, et al. Scorpion envenoming caused by Tityus cf. silvestris evolving with severe muscle spasms in the Brazilian Amazon. Toxicon 2016; 119: 266-269. doi:10.1016/j.toxicon.2016.06.015

22. NEJATI J, et al. Scorpion fauna and epidemiological aspects of scorpionism in southeastern Iran. Asian Pac J Trop Biomed 2014; 4: S217-21.

23. NUNES CS, et al. Aspectos demográficos e espaciais dos acidentes escorpiônicos no Distrito Sanitário Noroeste, Município de Belo Horizonte, Minas Gerais, 1993 a 1996. Cad. Saúde Pública, Rio de Janeiro, 2000;16(1): 223-213.

24. OLIVEIRA HFA, et al. Epidemiologia dos acidentes escorpiônicos ocorridos na Paraíba - Nordeste do Brasil. Rev Biol Farm. 2012;8(2):86-96.

25. ORTIZ E, et al. Scorpion venom componentes as potential candidates for drug development. Toxicon. 2015; 93:12535.

26. PEIGNEUR S, et al. A gamut of undiscovered electrophysiological effects produced by Tityus serrulatus toxin 1 on Nav-type isoforms. Neuropharmacology. 2015; 95: 269-277.

27. PUCCA MB, et al. Experimental Tityus serrulatus scorpion envenomation: age- and sex-related differences in symptoms and mortality in mice. J Venom Anim Toxins Incl Trop Dis 2011; 17(3): 325-32.

28. QUEIROZ AM, et al. Severity of scorpion stings in the Western Brazilian Amazon: A case-control study. PLoS One.2015; 10: 1-14. 
29. RECKZIEGEL GC. Análise do escorpionismo no Brasil no período de 2000 a 2010. Rev. Pan-Amaz Saúde. 2014; 5, 68.

30. RODRíGUEZ-RAVELO R, et al. The Cuban scorpion Rhopalurus junceus (Scorpiones, Buthidae): component variations in venom samples collected in different geographical areas. J Venom Anim Toxins incl Trop Dis. 2013; 19(1) $: 13$

31. SANTOS MSV, et al. Clinical and Epidemiological Aspects of Scorpionism in the World: A Systematic Review. Wilderness Environ. Med. 2016; 27: 504-518. doi:10.1016/j.wem.2016.08.003

32. SILVA NA, et al. Effects of tityus stigmurus (thorell 1876) (scorpiones: Buthidae) venom in isolated perfused rat kidneys. An. Acad. Bras. Cienc.2016; 88, 665-675.

33. SINAN. Acidente por animais peçonhentos - notificações registradas no sistema de informação de agravos de notificação, 2018.

34. TAN HH, MONG R. Scorpion stings presenting to an emergency department in Singapore with special reference to Isometrus maculatus. Wilderness Environ Med. 2013;24(1) :42-7

35. ULUĞ M, et al. Scorpion envenomation in children: na analysis of 99 cases. Turk J Pediat. 2012; 54:119-127.

36. VENTER O, et al. ARTICLE Sixteen years of change in the global terrestrial human footprint and implications for biodiversity conservation. Nat. Commun. 2016; 7: 1-11.

37. VEYRET Y. Os riscos: O homem como agressor e vítima do meio ambiente. 2. ed. São Paulo: Contexto, 2013.

38. XU SC, et al. Zhong Yao Cai [Study on spatial distribution pattern and seasonal distribution of Buthus martensii in yan'an]. 2013;36(12): 1914-7, 2013.

39. WENTZ EA, et al. Supporting global environmental change research:A review of trends and knowledge gaps in Urban remote sensing. Remote Sens. 2014; 6: 3879-39052014

40. ZHAO M, LIUX. Reprint of: Regional risk assessment for urban major hazards based on GIS geoprocessing to improve public safety. Safety Science. 2016; 87: 18-24. 